Original Research Article

\title{
Study of femoral neck fractures in elderly patients of Malayalam population
}

\section{Jayakrishnan Rajasekharan*}

Department of Orthopedics, Azeezia Medical Collage, Meeyannoor, Kollam, Kerala

Received: 11 June 2019

Revised: 14 August 2019

Accepted: 16 August 2019

\section{*Correspondence:}

Dr. Jayakrishnan Rajasekharan,

E-mail: jkrishnan_r@yahoo.co.in

Copyright: (c) the author(s), publisher and licensee Medip Academy. This is an open-access article distributed under the terms of the Creative Commons Attribution Non-Commercial License, which permits unrestricted non-commercial use, distribution, and reproduction in any medium, provided the original work is properly cited.

\section{ABSTRACT}

Background: 53 elderly patients aged between 51 to 80 were operated for fracture of neck of Femur to compare the two methods for early healing.

Methods: All patients selected for bipolar hemiarthopalsty. Out of them 25 were cemented, and 28 were uncemented. Every patients was operated through posterior (Southern- Moore) approach. Harris Hip score was studied to assess the duration of improvement.

Results: History of the patients was 12 (22.6\%) were diabetic mellitus, 14 (26.4\%) were Hypertensive 9 (16.9\%) were alcoholic, $18(33.9 \%)$ were normal (NAD) in the comparison of Harris Hip score at different age-in 51-60 years mean value was $92.8,(\mathrm{SD} \pm 0.3)$, in 61-70 years mean value was $85.1(\mathrm{SD} \pm 0.26)$, in 71-80 years mean value was 81.9 $(\mathrm{SD} \pm 0.26)$, On total sum of score was 729.6 , DF was 51 , MSS was $363,0.07, \mathrm{~F}=$ ratio was 5019 , p value was highly significant $(\mathrm{p}<0.01)$. In the comparative study of Harris Hip score degrees in both methods were quite functional, chisquare test was $3.90 \mathrm{DF}=3$, and $\mathrm{p}>0.05$.

Conclusions: This study of bipolar hemiartho pasty with cement or without cement will be quite effective to treat the neck fracture in old patients due to its dual fixation because calcar femorale present in the neck of the femur become function less with advancement of age moreover neck of the femur is devoid of periosteum Hence healing of neck fracture of the femur is medical challenge.

Keywords: Bipolar hemiarthroplasty, Harris hip score, No abnormal disease, Malayalam

\section{INTRODUCTION}

Fractures of the neck resulting from ground level falls or high energy trauma are common in patients in all ages especially in elderly patients. ${ }^{1,2}$ They can be challenging to treat, as femoral neck lacks periostem and therefore relies on direct healing leading to higher rates of nonunion or osteo-necrosis of femoral head. ${ }^{3}$ Additionally, these injuries frequently occur in patients with medical co-morbidities making the prospect of extensive, complex operations and possibly revision of surgery daunting. ${ }^{4}$
Anthroplasty or hemi arthroplasty is usually the treatment of choice for elderly patients, these fractures occur most commonly in elderly females and are un-common in patients under the age of 60 years Hemiarthroplasty procedure introduced in 1940, and still accepted as optimum treatment for displaced femoral neck fractures. Unipolar or bipolar arthroplasty is based on charnley's pioneering arthoplasty principles. Bipolar arthroplasty introduced in 1979 which is self-articulating prosthesis. ${ }^{5}$ The advantage of the bipolar hemiathroplasty is a better range of motion and reduction of acetabular wear (erosion and protrusion) due to dual bearing system, which incorporates articulation between the inner head 
and shell, shell and acetabulam. The present study was to evaluate the advantages cemented and un- cemented bipolar hemiarthroplasty in elderly patients with intracapsular femoral neck fractures, and determine the factors affecting the early healing of neck fractures of femur.

\section{METHODS}

53 patients were had neck of femur fracture admitted at orthopedic ward of Azeezia Medical College Hospital meeyannor, Kollam, Kerala the patients were operated with bipolar hemiarthoplasty.

All patients were operated through posterior (Southernmoore) approach, post operatively all patients received antibiotics and venous thrombo-embolism prophylaxis as per protocol partial weight bearing was on allowed on 4$5^{\text {th }}$ day. This research work was approved by Ethical committee of Azeezia Medical College meeyannoor, Kollam, Kerala. The duration of study about four years (April 2014 to July 2018).

\section{Inclusive criteria}

Patients $<50$ to $>80$ years of age having fracture of neck of femur. 25 patients cemented and 28 were uncemented based on the patients general condition and pre-injury mobility status.

\section{Exclusion criteria}

The patients suffering with malignancy and neurological problems were excluded from the study.

\section{Statistical analysis}

History of the patients were numbered, grouped with percentage, cemented and un cemented operated results were classified as per Harris Hip score methods, Harris Hip score was classified at different age groups. The statistically data was analyzed in the Microsoft 2007 software The ratio of male and female was 1:2.

\section{RESULTS}

History of the patients with femoral neck fractures-12 $(22.6 \%)$ had diabetic mellitus, 14 (26.4\%) were Hypertensive 9 (16.9\%) were alcoholic 18 (33.9\%) were normal (no abnormal disease) (Table 1).

Table 1: History of patients with femoral neck fracture $(n=53)$.

\begin{tabular}{|lll|}
\hline Particulars & No. of patients & $\%$ \\
\hline Diabetic mellitus & 12 & 22.6 \\
\hline Hypertensive & 14 & 26.4 \\
\hline Alcoholic & 09 & 16.9 \\
\hline Normal (NAD) & 18 & 33.9 \\
\hline
\end{tabular}

Table 2: Comparative study Harris Hip score degrees in both methods $(n=53)$.

\begin{tabular}{|llllll|}
\hline Harris Hip score & Poor & Fair & Good & Excellent & Total \\
\hline Cemented & 3 & 2 & 12 & 8 & 25 \\
\hline Un-cemented & 0 & 4 & 15 & 9 & 28 \\
\hline
\end{tabular}

Table 3: Comparison of Harris Hip score in different age group.

\begin{tabular}{|llll|} 
& Harris hip score in & Harris hip score in & Harris hip score in \\
& $\mathbf{5 1 - 6 0}$ years & $\mathbf{6 1 - 7 0}$ years & $\mathbf{7 1 - 8 0}$ years \\
\hline No. of patients & 12 & 32 & 09 \\
\hline Mean & 92.875 & 85.181 & 81.965 \\
\hline SD & 0.362 & 0.263 & 0.049 \\
\hline
\end{tabular}

Table 4: Comparative study of Hip score during treatment.

\begin{tabular}{|llllll|}
\hline Source & Sum of squares & df & MSS & F-ratio & p value \\
\hline Between treatment & 726.126 & 02 & 363.0645 & 5019.98 & p $<0.01$ \\
\hline Within treatment & 3.5439 & 49 & 0.0723 & & \\
\hline Total & 729.672 & 51 & & & \\
\hline
\end{tabular}

MSS: mean sum of squares; DF: Degree of freedom; F: ratio keeps as it is test statistic.

In the comparative study of Harris Hip score degrees in both methods. The chi-square test was 3.90 and df was 3, and $\mathrm{p}$ value was insignificant $(\mathrm{p}>0.05)$ (Table 2$)$.

In the comparison of Harris Hip score study in both cemented and un-cemented methods mean value in 51-60 years age was $92.8( \pm 0.3)$, mean value in $61-70$ years age was $85.1( \pm 0.2)$ and mean value in $71-80$ years age was $81.9( \pm 0.04)$ (Table 3). DF was 51, MSS was 363. Between the treatments 0.07 within the treatment F-ratio was 5019. $\mathrm{p}$ value was highly significant $(\mathrm{p}<0.01)$ (Table 4). 
Statistically there is highly significant $(p<0.01)$. Difference observed in Harris Hip score of different age group. It is maximum in the age group 51-60 and minimum in the age group 71-80. Harris Hip score is reducing from age group 51-60 to age group 71-80.

\section{DISCUSSION}

In the present study of femoral neck fractures in elderly patients of Malayali population. The history of the patients was $12(22.6 \%)$ were diabetic mellitus, 14 (26.4\%) were Hypertensive, 9 (16.9\%) were alcoholic 18 $(33.9 \%)$ were NAD (Table 1). Comparative study of Harris Hip Score degrees in both methods- cemented were 25 , un-cement were 28 , chi- square test was 3.90 , $\mathrm{df}=3$ and $\mathrm{p}$ value was $(\mathrm{p}>0.05)$ insignificant (Table 2$)$. It has been proved that, both methods were successful. In the comparison of Harris Hip score in different age group in 51-60 years the mean value was $92.8( \pm 0.36)$. In $61-70$ years of age mean value was $85.18,( \pm 0.26)$ in the age group 71-80 mean value was $81.9( \pm 0.04)$ total sum of square was $729.6, \mathrm{df}=51, \mathrm{MSS}=363.0,0.072, \mathrm{~F}$ ratio was 5019.9 and $\mathrm{p}$ value was highly significant $(\mathrm{p}<0.01)$ (Table 3 and 4). This findings were more or less in agreement with previous studies. ${ }^{6-8}$

In the present study, hypertensive, diabetic was also treated with their respective diseases before surgery and alcoholic were treated with extra calcium supplements.

Apart from this successful bipolar hemiarthroplasty. The pain may persist in many patients the reason for persistence in pain could be improper prosthetic seating, tissue reaction improper sized femoral head, contractures, peri-articular ossification, toggle or acetabular wandering and redundant ligament hence instead of cursing bipolar hemi orthoplasty. ${ }^{9}$ These factors has to evaluated And limping observed in hemiarthoplasty could be due to alteration in adductor mechanism caused by greater excision of neck. ${ }^{10}$

It was observed that, cemented bipolar arthroplasty had minimum pain, better mobility, and no significant difference in complications when compared with uncemented bipolar hemiarthroplasty. ${ }^{11}$ The posterior approach was used for bipolar hemiarthroplasty, is known for increased rate of dislocation Hence rate of dislocation was minimized with repair of posterior capsule and posterior soft tissue.The proper placement of implants is the utmost importance to minimize the complications

Although hip joint is strengthened by trabaculaes and trajectories of femur, which are crystallized line force which safe guard joint in every movements. In the present study dislocation was very rare. ${ }^{12}$ Hence it can be hypothesized that most of the fracture occur due to pre judicial or pre-predicted phobic state because drunken man with relaxed muscle often escapes injury, fractures in circumstances where a man with tensed muscle, ligament would suffer fractures. Hence it can be presumed that, phobic state of mind may be important contributing factor to cause fracture and delay in healing of fracture too, because skeletal structures have ability to meet the changing demands and restore their structural integrity and functional efficiency after they have suffered damage.

\section{CONCLUSION}

The present study of femoral neck fractures in elderly patients of Malayalam population. There was no significant different in cemented or un-cemented bipolar prosthesis, Hence bipolar prosthesis was safe option in treating fractures of neck in elderly (above 50 year). With good recovery and pain free, in-spite of having several co-morbidities. Usage of un-cemented bipolar also helped in easy revision to cemented total hip orthoplasty. But this study demands further, patho-physiological, biomechanical, nutritional, embryological, genetic study because the factors which heal the fractures bone are still un-clear.

\section{Funding: No funding sources}

Conflict of interest: None declared

Ethical approval: The study was approved by the institutional ethics committee

\section{REFERENCES}

1. Pauyo.T, Drager J, Alberts A. Management of femoral neck fractures in the young patients: a critical analysis review. World J Orthop. 2014;18(5):204-17.

2. Miyamoto RG, Kaplan KM, Levine BR. Surgical management of hip fractures an evidence based review of the literature. Femoral neck fractures $\mathbf{J}$ Am Acad Orthop Surg. 2008;16(10):596-607.

3. Slobogean GP, Sprague SA. Complications following young femoral neck fractures. Injury. 2015;46(3):484-91.

4. Zuckerman JD. Hip fracture. $\mathrm{N}$ Engl Med. 1996;334(23):1519-25.

5. Ennis J, Gilberty B. Single assembly total hip prosthesis; preliminary report. Orthop Dig. 1974;2:15-9.

6. Enocson A, Mattison L. Hip arthroplasty after failed internal fixation of tronchanteric and subtranchateric fractures. Acta Orthop. 2012;83(5):493-8.

7. Mabry JM, Prapa B. Long term results of THA for femoral neck fracture non-union. J Bone Joint Surg Am. 2004;86(10):2263-7.

8. Nwachulawu, Bozic KJ. Updating the cast effectiveness analysis in orthopedic surgery resilience of the 5000 per QALY threshold. J Arthoplasty. 2015;30(7):1118-20.

9. Lance Ford EM. Use of Moore-Self-locking vitallium prosthesis in acute fractures of the femoral neck. J Bone Joint surg. 1965;47:832-41. 
10. Hinchey JJ, Day PL. Primary prosthetic replacement in fresh femoral neck fractures. J Bone Joint Surg. 1960;42:633-40.

11. Parker MJ, Guruswamy K. Anthroplasties (with or without bone cement) for proximal femoral fractures in adults. Cochrane Database Syst Rev. 2006;3:CD001706.
12. Bochner RM, Pellicci PM. Bipolar hemiarthoplasty for fracture of femoral neck. J Bone Joint Surg. 1988;70:1001-10.

Cite this article as: Rajasekharan J. Study of femoral neck fractures in elderly patients of Malayalam population. Int J Res Orthop 2019;5:1207-10. 